\title{
EARLY ENTANGLEMENT OF NOVA SCOTIAN MARINE ANIMALS IN PRE-PLASTIC FISHING GEAR OR MARITIME DEBRIS: INDIRECT EVIDENCE FROM HISTORIC 'SEA SERPENT' SIGHTINGS
}

\author{
ROBERT L. FRANCE \\ Department of Plants, Food and Environmental Science \\ Dalhousie University \\ Truro, NS, Canada, B2N $5 E 3$
}

\begin{abstract}
Marine environmental historians and ethnobiologists have resorted to imaginative means with which to back-cast the temporal frame of reference in order to assess recent anthropogenic changes. The present study, in support of previous work from around the world, indicates that anecdotal accounts from eyewitnesses of purported sightings of sea serpents provides indirect evidence that marine animals in Nova Scotia have been subjected to anthropocentric pressure for a much longer period than commonly presumed. This involves not only direct fishery exploitation, but also perhaps from being bycatch due to entanglement in deployed gear.
\end{abstract}

Key words: Unidentified marine object, entanglement, fishing gear

\section{INTRODUCTION}

One challenge faced by environmental scientists and historians occupied with documenting changes in the Anthropocene is the need to back-cast the temporal frame of reference in order to detect recent alterations. Occasionally this task can be accomplished without too much difficulty due to comprehensive notes kept by a few early scientists. One such case involved the meticulous phenological records tabulated from schoolchildren across Nova Scotia by Alexander Mackay (France 2010), thereby enabling assessment of climatic changes in the province (Vasseur et al. 2001, Culbertson-Paoli et al. 2019). Often, however, data sets collected by early 'citizen scientists' require much more work before they can be made of use. This is due to having to sort through unorganized, so-called 'shoebox' files of disparate observations, or the need to extract information carefully

\footnotetext{
* Author to whom correspondence should be addressed: rfrance@dal.ca
} 
from that embedded in the often voluminous journals of natural historians (France 2010), as for example completed by Miller and Primack (2008).

That the world's marine ecosystems have undergone extensive alteration in consequence of human activity is widely accepted (e.g. Starkey et al. 2007; Bolster 2012). By analyzing catch records through time, marine scientists and historians have played a key role in documenting the deleterious alterations to global fisheries (e.g. Lotze et al. 2006, Lotze \& Worm 2009). Such work relies upon a temporal consistency in the type of data being compared for assessing biological changes. However, obtaining such data is not always possible. In these cases, surrogates are needed from which to indirectly infer anthropogenic changes in variables of premier interest, as for example, shifting baselines (Pauly 1995; McClenachan et al. 2012). Some marine scholars have resorted to imaginative means by which to estimate past conditions and to indirectly measure recent anthropogenic changes (Camuffo 2001, McClenachan 2009, Drew et al. 2013, Rice et al. 2017). Other work is based on the qualitative examination of historical accounts from eyewitnesses (e.g. Mowat 1999). Studying dynamic relationships between people, the biota, and their shared environment through time, falls within the purview of environmental history, historical ecology, and ethnobiology.Together these play an integral role in conservation biology and natural resource management (e.g. Crumley 1994, Pauly 1995, Meine 1999). Ethnobiology can contribute to historical ecology through the use of anecdotal information, often compiled from a wide variety of nonscientific textural sources (e.g. Al-Abdulrazzek et al. 2012, da Silva et al. 2014, McClenachan et al. 2012, Saenz-Arroyo et al. 2005, 2006). This sort of work falls within the bailiwick of natural history, so it is neither appropriate to prejudicially dismiss the value of information contained within historical textual accounts (Pauly 1995), nor to insist upon rigorous hypotheses testing as per scientific procedure. The two approaches are very different (Peters 1980, 1991). Exclusively focusing on biophysical records while ignoring social ones can severely limit the usefulness of research undertaken to understand and manage complex social-ecological systems, such as the marine littoral (France 2016a), in the Anthropocene (Dearing et al. 2015).

In his comprehensive history of the North American fishery, Bolster (2012) made the bold assertion that "no marine environmental historian worth his or her salt can afford to ignore...nineteenth-century 
sea serpents." Mining the literature of folkloric tales and eyewitness accounts concerning sea monsters can indeed offer ecological and ethnobiological insights (e.g. Parsons 2004, Narchi et al. 2013, Szabo 2018, Paxton \& Naish 2019). In this respect, the present historical investigation in support of previous work (France 2016b,c, 2017, 2018, 2019a,b,c), suggests that textural records by laypeople provide surrogate information about the history of deleterious interactions between humans and marine animals. In particular, my thesis is that a careful parsing of the words contained in the anecdotal accounts of purported sea serpent sightings generate data (sensu Paxton 2009) to serve as a valuable resource. Such an approach can extend inferences made about what is today acknowledged as being one of the most serious threats to marine biodiversity, namely, the entanglement of bycatch in fishing gear or other maritime debris.

\section{THE CASE OF THE GLOUCESTER 'SEA SERPENT'}

There have been hundreds of sea serpent sightings made from every conceivable corner of the globe over the last four centuries (Oudemans 1892). The centre for the greatest number of sightings has been the Northwest Atlantic seaboard (Heuvelmans 1968). More than two hundred and fifty sightings have occurred in New England (O'Neill 1999), and eighty in Atlantic Canada (France, in prep.), with at least half of the latter being in Nova Scotia waters (Hebda 2015).

Most sightings of sea serpents are either of an extremely brief duration or made by a single observer. This is not the case, however, with respect to the so-called 'Gloucester Sea Serpent' which frequented the Massachusetts and New York coasts during the early nineteenth century. Being observed by hundreds, if not thousands, of people, from all walks of life, often for durations of many minutes, and in some cases, even hours (Soini 2010), this particular unidentified marine object (UMO) remains the most sighted sea serpent in history (France 2019a). Another unique feature about the Gloucester Sea Serpent is that it is the most thoroughly investigated such creature of all time. The social 'phenomenon' (sensu Burns 2014) created by reports of the Gloucester Sea Serpent led to detailed interviews of eyewitnesses. These were conducted by legal authorities under the auspices of the region's learned natural history society, the Linnaean Society of New England. These took place soon after the bulk of the 
sightings and played an important role in international discussions concerning the theory of evolution and in the birth of American science (Brown 1990, Lyons 2009, France 2019a). This is the reason why the Gloucester Sea Serpent forms such an important lynchpin in the theories touted by cryptozoologists in terms of being "by far the best-documented evidence that sea-serpents exist" (Bauer 2013).

The most notable behavioral feature (France 2019a) of the Gloucester UMO was its rapid speed of movement (which often produced a massive trailing wake). Eyewitnesses noted the remarkable flexibility of the UMO, which twisted and turned upon itself, coiling and uncoiling quickly with different portions of its body capable of moving side-byside in diametrically opposing directions. Elements comprising the elongated body of the UMO were observed to independently undulate in an up and down motion as if floating on the surface. Sometimes, the entire bulk of the UMO was seen to be pulled downward, quickly disappearing into the depths with little or no warming, sinking as if a stone. At other times, the UMO was seen floating motionless upon the water, occasionally for extended periods. Intriguingly, the portion of the UMO observed above the sea surface appeared to be totally oblivious to its surroundings, including, most remarkably, to even being hit by musket shot, harpoons, and in one case, even a cannon!

The most notable anatomical feature (France 2019a) of the Gloucester UMO was its considerable or "monstrous" length, ascribed by eyewitnesses to being up to a hundred feet. The UMO was observed to have neither a discernable tail, nor any appendages. The UMO's component body parts, including the premier one which was taken to be the head, were frequently likened to being of a size similar to that of a keg, cask, barrel, or firkin (a small container used for holding liquids or butter). The bulk of the UMO's length was composed of a series of irregular or uneven, loosely articulated joints, humps, or bunches, sometimes identified as being of variable number (ranging from less than ten to more than fifty). Significantly, a number of accounts specifically describe the UMO's body as resembling a string or a chain of buoys, corks, or kegs tied or roped together and floating upon the surface (Table 1). This is the closest we have to a 'smoking gun' in terms of identifying that the UMO was actually an entangled animal; i.e. the so-called 'duck test' (i.e. 'if it looks like a duck, swims like a duck, and quacks like a duck, then it probably is a duck") for abductive reasoning. 
The Gloucester unidentified marine object (UMO), folklore's most famous sea monster, occurred coincidentally with history's most significant volcanic eruption that also led to the birth of literature's most famous monster, Frankenstein (France 2019c). The 1815 eruption of Tambora in Indonesia produced a social-environmental crisis around the world (Wood 2014). In New England, propagated changes completely transfigured the relationship of humans to their coastal ecosystem (Alexander et al. 2017). Slaughter of livestock occurred from want of fodder, and collapse of the anadromous fisheries due to spawning failures. This necessitated turning to the sea for food protein in extremis. Beginning in 1816, and motivated by desperation and the threat of starvation, the entire northeastern coast of America, as never before, became covered by a network of lines and deployed fishing nets. Netting was used to catch mackerel as well as herring and menhaden; the latter was used as baitfish for jigging. The result was a seascape primed to create a sea serpent through bycatch entanglement in fishing gear.

Once the switch to offshore fishing was made, it stuck. There was simply no going back to small, shore-hauled nets and weir-traps straddling streams and rivers, when larger nets could be deployed in coastal bays and offshore waters to collect more biomass. The result was a parallel and progressive rise throughout the rest of the century in New England of both entrapped small fish (Alexander et al. 2017) and bycatch-entangled animals misconstrued as sea serpents (France 2019c).

The same social-ecological emergency caused by the extreme climatic changes arising from the Tambora eruption also affected Atlantic Canada in an identical fashion (Harrington 1992). The purpose of the present environmental history investigation was to determine if anecdotal evidence exists that is similar to that of New England for inferred entanglement in the accounts of sea serpent sightings around Nova Scotia.

\section{HISTORICAL DESCRIPTIONS OF NOVA SCOTIAN 'SEA SERPENTS' SUGGESTIVE OF ENTANGLEMENT}

In mari multa latent, goes the old adage: "in the ocean many things are hidden." Similarly, Fama (2012) believed that truth behind sea serpents is often "hidden in the plain language of their own 
Table 1 Descriptions of the UMO, imagined as a sea serpent, observed between 1815 and 1824 in Gloucester Harbor and elsewhere, and clearly indicative of a marine animal entangled in fishing gear or other maritime debris (France 2019a,c).

“...his appearance in this situation was like a string of buoys. I saw perhaps thirty or forty of those protuberances and bunches, which were about the size of a barrel."

"...looked like the buoys of a seine"

"...with a good glass [I saw what] seemed like gallon kegs tied together"

"His body when out of the water looks like the buoys of a net, or a row of kegs, or a row of large casks"

“...of the size of a barrel about the body, which... are so prominent, that they resembled buoys attached to each other"

"[The body] appears in joints like wooden buoys on a net rope almost as large as a barrel, that the musket balls appear to have no effect on it, that it appears like a string of gallon kegs."

"...as he moved he looked like a row of casks following in a right line"

"He appears to be full of joints and resembles a string of buoys on a net rope, as is set in the water to catch herring. Others describe him as like a string of water casks...Two [musket] balls were thought to hit his head, but without effect."

"...resembled the link of a chain."

"The first view I had of him appeared like a string of empty barrels tied together, rising over what little swell of the sea there was."

"The back was composed of bunches about the size of a flour barrel, which were apparently about three feet apart... and looked like a string of casks or barrels tied together."

"The body, which is formed into parallel rings, which - when he is on the top of the water-are so prominent, that they resembled buoys attached to each other."

“... and to seem jointed, or like a number of buoys or casks following each other in a line."

“...the curvature and bunches on his back. To some he appeared jointed, or like a string of kegs or buoys connected on a rope."

"...giving the appearance of a long moving string of corks."

descriptions." In this spirit, the corpus of accounts of Nova Scotian UMO sightings complied by Hebda (2015) and France (in prep.) were carefully examined. The anecdotes most suggestive of an entangled animal are described in abbreviated form below. The full texts can be found in Hebda (2015) and France (in prep.), with the former including some of his interpretive drawings of the described creatures.

At the height of the Gloucester sea serpent phenomenon which gained world-wide attention in 1817, William Less, a former consul of the United States at Bordeaux and an accountant in the treasury department, wrote a letter to the learned naturalist Dr. Mitchell. 
In this, he described a trip he had made as a boy from Quebec, in 1787, aboard a schooner. While heading through the Gut of Canso, Cape Breton Island, a crew member warned that the schooner was heading directly for a shoal, which to their "great astonishment" moved past them, and in so doing, pulled its elongated body across the bow of the vessel, whereupon they "discovered it to be an enormous Sea Serpent, four times at least as long as the schooner. Its back was of a dark green color, forming above the water a number of little hillocks, resembling a chain of hogsheads [i.e. barrels]." The UMO's head was described as being the size of large as the small dory, and its passage made "a tremendous ripple and noise," comparable to that of the launching of a ship [Anecdote 1: Niles Register, September 20, 1817 in O'Neill 1999].

In 1825, a gentleman,"whose character, whose education and scientific attainments render it impossible that he could either be deceived or willfully misrepresent the facts was traveling with several ladies along the shore of the Bedford Basin, Halifax Harbour, when "their attention was arrested by the appearance of a black object upon the surface of the water" about sixty feet distant. As the UMO moved forward by wiggling its body without showing any fins, the gentleman concluded the "it could be no other animal but a sea serpent." Subsequent observation made over a five-minute period, we are told, confirmed his first impression. It included the head being raised about three feet above the water before dipping back down, and a note that the "after part of the body raised a coil which warped itself along to the tail, and this made it to be supposed that its extreme its length was at least $60 \mathrm{ft}$. Its colour appeared to be black, and it appeared to be in circumference about the size of a large log." Another observer who "had a distinct view of this monster" and whom "felt satisfied that it was a sea serpent" remarked that it "moved round the boat in a sweeping and circular direction" and possessed "eight coils of the body above the water, each about a yard in length and with the same space intervening between them," for a length of sixty feet. The UMO was observed to move with great rapidity so as to leave a trailing wake but was oddly devoid of any discernable fins to account for the propulsion [Anecdote 2: 'Sea Serpent at Halifax,' The Nova Scotian, July 27, 1825].

In 1838, multiple eyewitnesses in the fishing village of Meteghan, near Yarmouth on the southern tip of Nova Scotia, saw what they 
first thought to be a large shark or whale producing a notable wake in the water. Upon closer inspection, however, the UMO was of an incredible length of up to one hundred and fifty feet, and held its head, likened to being the size of a large barrel, above the water. The creature swam within an oar's length of the boat, yet ignored them completely, as if the head was oblivious to their presence [Anecdote 3: Dearborn 1998].

The UMO that was observed swimming past the pier at Arisaig, Cape George, in 1844, had a sixty-foot long body of a thickness of three-feet. The description reads like Heuvelmans' (1968) typical many-humped "chain of floats" sea serpent, such as that seen in Gloucester Harbour:

It had humps on the back, which seemed too small and close together to be bends of the body. The body appeared to move in long undulations, including many of the smaller humps. In consequence of this motion, the head and tail were sometimes both out of sight, and sometimes both above water, as represented in the annexed outline, given from memory [Fig 1]. The head...was rounded and obtuse in front, and was never elevated more than a foot above the surface. The tail was pointed, appearing like half of a mackerel's tail. The colour of the part seen was black [Anecdote 4: Lyell 1850].

The following year, a similar (or the same) UMO was observed further along the Northumberland Strait at Merigomish. Enough of a stir was caused by the report of the event to attract the attention of famed Scottish geologist Sir Charles Lyell. who was traveling in the Maritimes at the time. The UMO's head, which was occasionally raised above the water during the observation period of half an hour, was said by several eyewitnesses to resemble that of a seal. Once again, the remaining description matches that of the famous Gloucester Sea Serpent:

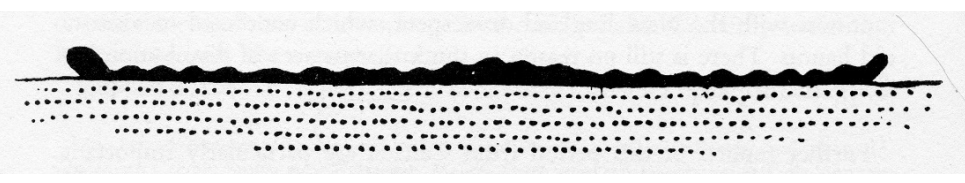

Fig 1 Huevelmans' (1968) interpretation of the UMO seen in 1844 off Arisaig, Nova Scotia, as described by Lyell (1850). 
Along its back were a number of humps or protuberances, which, in the opinion of the observer on the beach, were true humps, while the other thought they were produced by vertical flexures of the body. Between the head and the first protuberance there was a straight part of the back of considerable length, and this part was generally above water. The colour appeared black, and the skin had a rough appearance.

The animal was seen to bend its body almost into a circle, and again to unbend it with rapidity. It was slender in proportion to its length. After it had disappeared in deep water, its wake was visible for some time. There were no indications of paddles [i.e. flippers or fins] being seen. Some other persons who saw it compared the creature to a long string of fishing-net buoys moving rapidly about [Anecdote 5: Lyell 1850].

In 1846 , another (or possibly yet again the very same) UMO, noted to be about seventy to one hundred feet in length and of a steel-gray colour, was observed by three boaters, this time along the western shore of St. Margaret's Bay: "They saw that what they at first thought were floats of a long net, which began to move, leaving a wake as large as that of a schooner. They now perceived the object to be a large Serpent, with a head about the size of a barrel, and a body in proportion, and with something like a mane flowing down its neck. It carried its head erect, with a slight inclination forward." And as described in the later article: "[They] saw in the water at a distance, something which they thought to be a large fleet of nets...They were surprised, on again looking at the supposed fleet of net, to see it straightening itself out, and moving off so swiftly as to leave a wake." Reverend Ambrose concludes by stating that "I have not been able to ascertain the motion of these animals in swimming, whether vertical or horizontal in its sinuosities. Wilson's [one of the eyewitnesses] first idea of corks [author's own emphasis] would seem to indicate a succession of vertical motions" [Anecdote 6: Ambrose 1867, earlier read version from 1864 in Heuvelmans 1968].

In 1849, in the same location of St. Margaret's Bay, three fishermen spotted an UMO that resembled "an immense snake" of about sixty feet in length and with a circumference of the size of a puncheon, or cask. The men rowed out to examine the animal, which was strangely oblivious to their presence. Nearer inspection revealed the elongated 
creature to taper at both ends with no caudal fin present. Its back was composed of a "row of spines, each of about an inch in diameter at the base, erected along its back" in addition to a single very high dorsal fin. The latter resembled "in size and appearance the sail of a skiff" and which could be folded back into its body like the folding fin of a giant Bluefin tuna. Ambrose (1867) likens this structure to being a bristly mane. Furthermore, "the animal's back was covered with scales, about six inches long and three inches wide, extending in rows across [author's emphasis] the body, i.e. the longer diameter of the scale being in the direction of the circumference of the body." The UMO then raised its head, and opening its jaws, "showed the inside of its mouth red in colour and well armed with teeth about three inches long, shaped like those of a cat-fish [by which he probably means, barbels]" [Anecdote 7: Ambrose 1867].

The most detailed description of an encounter with a Nova Scotian sea serpent occurred in 1855 in Green Harbour, near the town of Shelburne, and was published eleven years later [Anecdote 8: Lord 1866]. It is also one of the more contentious narratives to come from the region. Some, such as Greg Ross (www.futilitycloste.com/2012/07/27), have questioned its veracity, as they deem it is unlikely that the author, a respected journalist who had worked for Scientific American, would have sat on such a sensational story for more than a decade. Hebda (2015) acknowledges that the literary stylistic elements verge on being purple prose, but concludes "when one examines the descriptive details provided in the text, one can see anatomical and behavioural elements that can only be derived from personal observation." Sadly, the author was not around long enough to be questioned, for several weeks following the article's publication, he took his own life while visiting the grave of his recently deceased wife. The anecdote begins on a hill overlooking the harbour, with Lord and other eyewitnesses observing fleet of fishing boats racing for the shore, where a group of women were shouting "The snake! The snake!" The UMO moved "slowly and majestically" but "fast enough to keep pace with the boats," and is thusly described:

Near what might be the head, rose a hump or crest, crowned with a wavering mass of long, pendulous hair like a mane, while behind, for forty or fifty feet, slowly moved, or rolled, the spirals of his immense snake-like body [Fig 2]. The movement was in vertical curves, the contortions of the back alternately rising and 

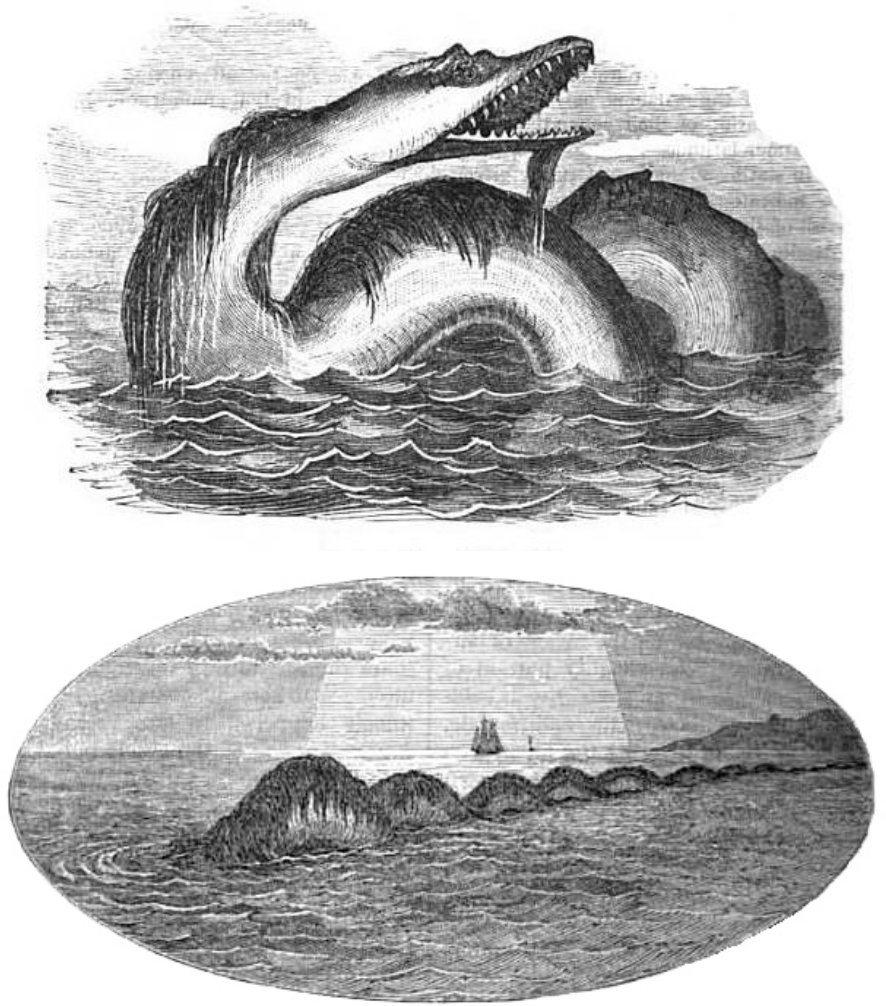

GOING OUT TO SEA.

Fig 2 Two illustrations of the UMO, imagined by the artist as a classic sea serpent, seen at Green Harbour, Nova Scotia in 1855 (Lord 1866). The upper image is quite similar to Pierre Belon's drawings in De aquatilibus libri duo (1553) which were used by Mercator in his famous world map of 1569 (see Van Duzer 2013).

falling from the head to the tail, leaving behind a wake, like that of a screw-steamer, upon the glassy surface of the ocean.

Unperturbed by the commotion, the UMO approached the shore and then raised its smooth and horny textured, "dark dingy-blue" head and opened its "horrid jaws," which were filled with "rows of glistening teeth," uttering a loud hissing noise. Significantly, "a long tuft of hair like a goat's beard" hung from its head, about which a mane "floated about the neck." The body is also described as being composed of a series of "scales which defended the hide, glistening in the sun." The next morning, while out in a boat fishing, the "monstrous denizen" 
from "the Unknown depths of Neptune's dark empire" approached to within an oar's length. This time the head is described as being "shell-like," a portion of the body being six or seven feet in diameter, with the rest of the shape displaying "an undulatory movement." Again an "immense mane" is noted that "flowed wavingly, either by the motion of the current or the convolutions of the body."

A schooner passing near Pictou Island in 1879 spotted "an enormous sea serpent" one hundred feet in length with a diameter the size of a barrel, which was moving at a rapid rate. At first the "great bulk" of the "terrible monster" appeared to suggest a whale. Closer inspection made the eyewitnesses change their mind when they saw "a bushy protuberance back of the neck" that some thought to be "a sort of mane" [Anecdote 9: 'A terrible Monster,' The Reading Daily Eagle, July 30, 1879 in Hebda 2015].

In 1905, a group of fishermen and wharf-side observers in Bras d'Or Lake (an inland sea on Cape Breton Island) saw a "leviathan" sporting a sixty-foot long snake-like body that moved at such a "terrible pace [so as to be] sending the spray from his head", similar to that of a small cutter going through the water. This 'head' would occasionally surface and swing "slowly from side to side," and most remarkably was impervious to being shot at, with the "rifle balls apparently doing little damage, other than producing a savage shaking of the body of the monster" [Anecdote 10: 'Curlew's Crew Saw Large Snake: Story of Thrilling Adventure in Nyanza' - Sydney Daily Post, July 18, 1905 in 'The Innocents Aboard, Local Sea Serpents: 3 Reports,' Cape Breton Magazine 32, 1982 and in Hebda 2015].

Five years later, and around the side of Cape Breton Island at Ingonish, passengers aboard a steamer observed a black object disturbing the water. The body of the UMO was composed of a series of "spots" that "protrude from the water, and look like a snake fence viewed across a grain-field [snake fences are of course inanimate objects made of roughly split planks joined in a zigzag pattern with their ends crossing]." The interviewed eyewitness is careful in his description of the UMO, referring to it as "this whole mass, procession or whatever it might have been." Whatever it indeed was, observers noted, it moved "rapidly away" [Anecdote 11: 'Mr. McDuff, First Sea Serpent of the Year Puts in an Appearance off the North Shore,' Sydney Daily Post, July 14, 1910 in 'Local Sea Serpents: 3 Reports,' Cape Breton Magazine 32, 1982 and in Hebda 2015]. 
Sydney Harbour was visited by an eighty-foot "sea-serpent" in 1939 that was capable of swimming at a rate of five to seven miles an hour. Described as being eel-shaped and as large as a ten gallon keg, little of the UMO was observed to be under, as compared to being over top of, the water. When swimming, "there would be one or two undulations coming up out of the water for 6 or 8 feet and the upper part of the undulations would come 4 or 5 feet out of the water." Overall, the eyewitness summed up the sighting simply as "No fins, just a big eel" [Anecdote 12: Huvelmans 1968].

\section{DISCUSSION}

\section{Entanglement: Materials and Non-Lethality}

Entanglement in marine debris and fishing gear is a serious environmental problem affecting the abundance and biodiversity of more than two hundred species of marine animals (Laist 1997). Significantly, for purposes of my thesis about the parsimonious (i.e. al à Occam's razor) explanation behind a portion of sea serpent sightings, is the fact that by no means every animal unfortunate to become entangled is fatally entrapped. Some can break free and remain non-lethally entangled in fishing gear or maritime debris for extended periods of months and even years (Johnson 2005). Fama (2012), for example, mentions a North Atlantic right whale named 'Necklace,' who was observed in the Gulf of Maine for a decade with a fishing net wrapped around her tail stock. Other entangled whales have been known to have traveled thousands of kilometres (Lyman in NOAA 2014, Anon. 2019a,b). Furthermore, the opportunity for an entangled animal to escape was much greater in days before the use of synthetic lines, which are much stronger and more elastic than hemp. In the past, a strong swimming cetacean, pinniped, or large fish could often muscle its way through gill nets made of cotton twine or hemp, "leaving behind a big hole and a frustrated fisherman" (Johnson 2005), and sometimes in the process, making off with portions of the net and its accompanying floats in tow.

Entanglement is widely believed to be a modern phenomenon related to the advent and widespread mid-century use of plastic (Wabnitz \& Nichols 2010, Vegter et al. 2014), with little or no occurrence before that time (NOAA 2014). This is due to the assumption that materials made from hemp and other natural fibres will "lose their 

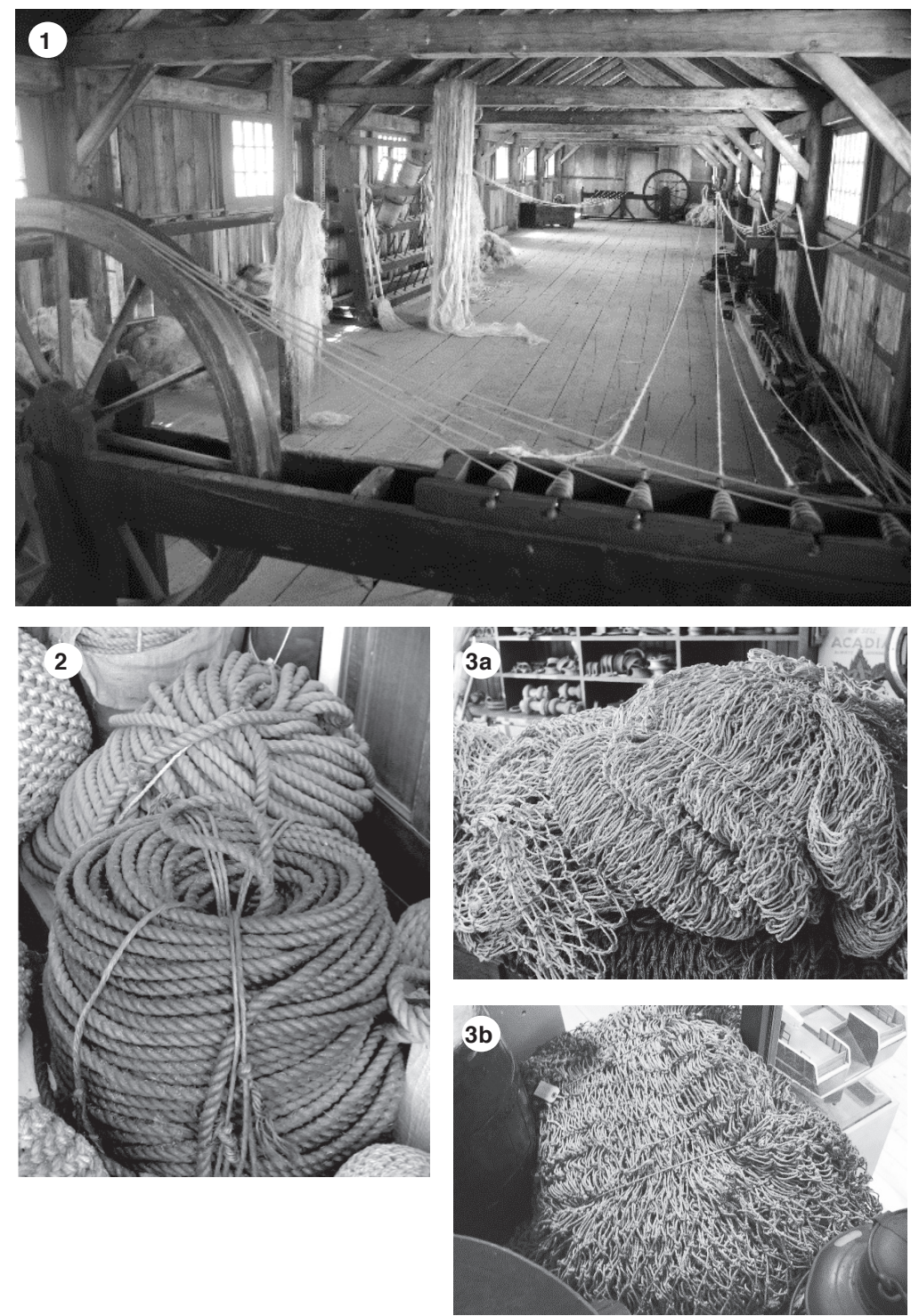

Fig 3 1. Nineteenth-century rope-walk where hemp ropes would be braided together (photo taken at the Mystic Seaport Museum, CT). 2. Natural fibre ropes were often treated with tar (note darkening colour of front coil) to increase longevity (photo taken at the Maritime Museum of the Atlantic, NS). 3a \& b. Fishing nets constructed of hemp (photos taken at the Maritime Museum of the Atlantic, NS and the Mystic Seaport Museum, CT). All photos from France (2019a). 
resilience in usage and if lost or discarded at sea [will] tend to disintegrate quickly" (Gregory 2009).

Compared to modern nylon or polyethylene ropes and nets, it is true that earlier ones made from natural hemp fibre (Fig 3) deteriorated more rapidly. But it would be erroneous to suppose that such material was not of sufficient durability for continued widespread use (Aiken \& Purser 1936, McCaskil 2009) and would have lasted long enough to pose a threat for entangling susceptible wildlife. Hemp ropes were often impregnated with dye or pine tar to extend their longevity (Kristjonsson 1971, Bekker-Nielsen \& Casola 2001). The rise in popularity of manila hemp during the nineteenth century was due to its natural oils that provided resistance to deterioration, thereby eliminating need for tar or other treatment to prevent deterioration.

Entanglement in the nineteenth and early twentieth centuries may have lasted, if not for half a decade or longer as today, due to nondegradable plastic, but at least for a few months, and possibly several years. This would certainly have been sufficient time for an unfortunately entangled animal to have been witnessed and misidentified as a sea serpent. An animal pulling a string of buoys, which during the nineteenth century shifted from being blown-glass balls to larger cork floats and even casks (Fig 4), through the water, could easily be misconstrued as the undulating motions of a supposed sea serpent. A NOAA spokesperson interviewed for his opinion about my thesis, is quoted as saying that "experts agree that anything left in the ocean could present an entanglement hazard for marine life," and the director of the entanglement response team with the Center for Coastal Studies on Cape Cod, confirms that "no doubt there has been an entanglement problem for as long as humans have been setting rope-based gear-plastic or not."

Animals in the Northwest Atlantic were susceptible to entrapment in fishing equipment long before Mount Tambora erupted. Fishing by Europeans in this region began by following Native techniques. This involved the use of weirs across rivers to trap anadromous fishes and it then progressed to inshore ground fishes, and finally to offshore pelagic species (Bolster 2012). Most fishing at the time of the Gloucester Sea Serpent sightings was undertaken through use of modest seines, gill nets, and hooks deployed from small boats. Baited hooks would be towed from outrigger poles and a "rat's nest of lines" (Bolster 2012). Filter-feeding menhaden could not be captured by mackerel jigs and 

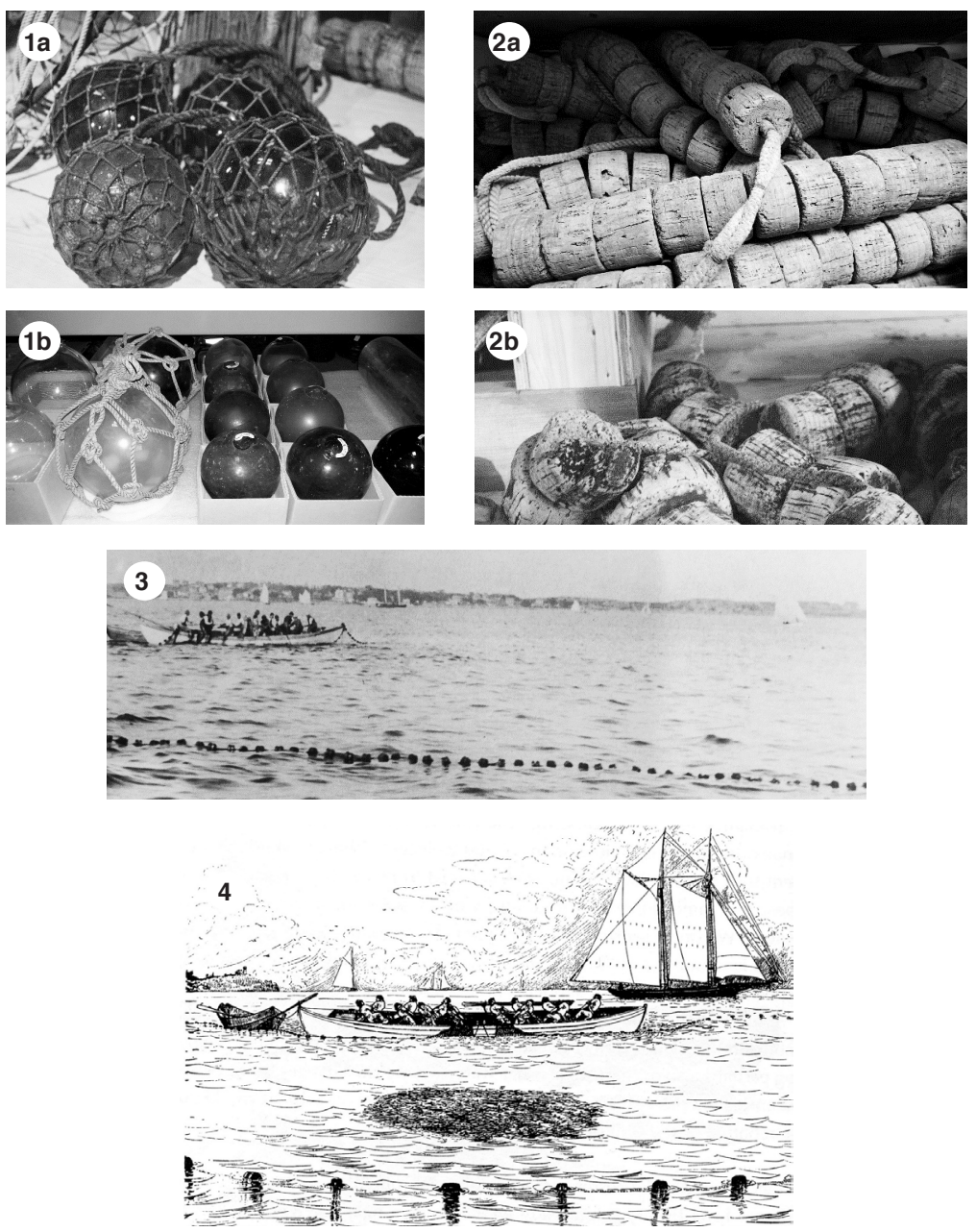

Fig 4 1a \& b. Blown-glass balls used as floats from the nineteenth century (photos taken at the Fisheries Museum of the Atlantic, NS and provided curtesy of the Mystic Seaport Museum Archive and Collections, CT). 2a \& b. Nineteenthcentury cork floats (photos provided curtesy of the Mystic Seaport Museum Archives and Collections, CT and also taken at the Fisheries Museum of the Atlantic, NS). 3. Strings of fishing net floats which, possibly festooned with accumulations of seaweed, and viewed from a distance while pulled behind an entangled animal, could easily give the impression of being the long tail of a sea serpent (photo taken at the Cape Ann Museum, MA). 4. Casks used to mark deployed fishing nets in the nineteenth century (Goode et al. 1884), which also viewed from a distance while pulled by an entangled animal, might look like a long tail of a presumed sea serpent, especially if also trailing a 'mane' of fishing net and attached seaweed. All images from France (2019a). 
had to be caught in beach seines. The nets for these were suspended from a head-rope buoyed by floats (Goode et al. 1884).

Additionally, during the eighteenth and nineteenth centuries, hemp nets were specifically set to entrap marine mammals (Mowat 1997). Seals and porpoises in the Gulf of Maine were then, as now, considered to be in competition with fishermen with respect to cod and mackerel. Indeed, one person collected a generous bounty for producing a staggering five hundred tails of porpoises over a twoyear period (Bolster 2012). A large-scale commercial net fishery also existed in the Gulf of St. Lawrence and southern Labrador for seal oil. Operating on the same principle as gill nets for fish, but made with stronger hemp twine, seal nets up to 83 metres long would be moored to the bottom two metres below with primitive anchors. They were kept perpendicular by a string of corks along a surface head-rope. As described by one fishermen, "as the seals dive along near the bottom to fish they strike into the net and are entangled" (Bolster 2012). Another technique, employed across narrow choke-points in shallow bays where seals were known to congregate, was to construct a semi-permanent frame of large nets to herd the pinnipeds into a pound which would then be hauled ashore via a capstan. In short, by the early nineteenth century, an obstacle course of deployed fishing nets existed along the Northwest Atlantic seaboard. These nets could entrap any large marine animal unfortunate to become entangled.

At this time, there were also fisheries that involved hunting animals such as whales, sharks, tuna, and other large fishes, using thrown harpoons (Fig 5). It is likely that some of these struck creatures would have survived for extended periods (Gardner 2007). Indeed, in preballistic times, as many as a quarter of all struck whales actually managed to evade capture. An account can be found from the noted polar explorer Fridtjof Nansen (see Mowat 1997 and France 2016b) who lost equipment to an escaping whale. One wonders if the next person who spotted Nansen's struck whale, pulling along its three intertwined ropes and series of large casks behind, imagined that it was a glimpse of the elusive sea serpent.

There must have been plenty of opportunities to invent a sea serpent in this way. For it is worth noting that the customary technique used over the centuries in harpooning, be it for whales or for tuna, is 'kegging,' wherein the harpoon line is tied to a single (Fig 5) or a series of wooden kegs which the struck animal tows about until it 
becomes exhausted and slows down enough to enable being caught and subsequently slain (Johnson 2005). "Usually," but by no means always, as for example when the harpoon head is not buried too deeply and works its way out, the entanglement persisted with the rope line wrapped around the head, caudal flukes or fins of the escapee, and sometimes with the head of the harpoon waving about in the air which could be misconstrued as being the serpent's tongue (as, for example, described for the Gloucester UMO, France 2019a).

\section{Entanglement: 'Sea Serpent' Evidence}

There is an absence of entanglement records prior to the middle of the twentieth century, which NOAA (2014) posit as being due to either the low use of synthetic materials in fishing gear and/or the general lack of awareness of the problem. For example, Balazs' (in NOAA 2014) 1985 survey of the published literature found no cases of entanglement of marine turtles before 1950. In their expanded survey on all species susceptible to entanglement in maritime debris, Vegter et al. (2014) identify only a few papers published on the subject prior to the 1970s. NOAA's (2014) own comprehensive survey records three
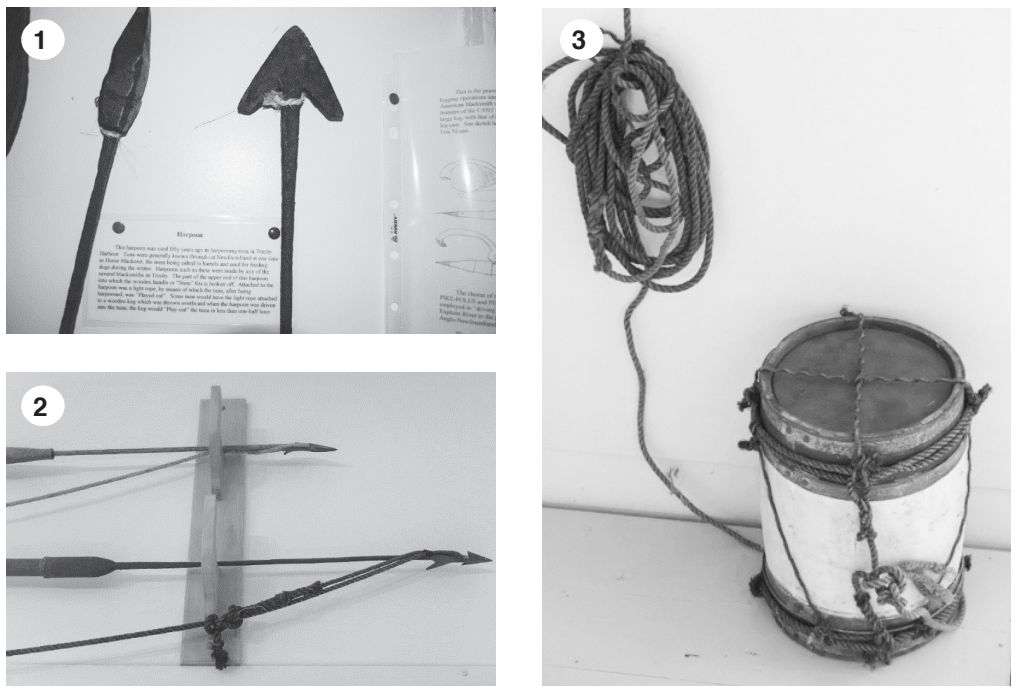

Fig 5 1. Fishing harpoons from the nineteenth century. 2. Fishing harpoons from the mid-twentieth centuries (photos taken at the Trinity Museum, NL and the Wedgeport Tuna Museum and Interpretive Centre, NS). 3. Kegging fishing gear (photo taken at the Wedgeport Tuna Museum and Interpretive Centre, NS). All photos from France (2019a). 
published articles on early pre-plastic entanglement, dating from 1923 for a seal, 1928 for a mackerel, and 1931 for a shark.

Given the lack of attention, until recently, paid by scientists to entanglement, one has to follow the lead of conservation biologists such as, e.g. Pauly 1995, Sanez-Arroyo et al. 2005, 2006. They have used non-standard descriptive sources to find such information. Some of these sources are historical accounts of fisheries. For example in the case of basking sharks, mention is made of the animals ruining nets following entanglement, accounts coming from the nineteenth and mid-twentieth centuries (Wilcocks 1884, Fairfax 1998, Wallace \& Gisborne 2006, Speedie 2017; see France 2019b for specific anecdotes extracted from these books). Basking sharks, because of their enormous size and their nose-to-tail surface swimming behavior, have a propensity for becoming entangled in fishing nets. Indeed, their Latin taxonomic name, Cetorhinus maximus, means 'pointy-nosed monster.' As a result they are likely candidates for being misidentified as sea monsters (Speedie 2017, France 2019b). It is therefore no coincidence that sea serpent sightings peak when basking sharks are abundant (Magin 1996), and this is also contemporaneous to when ruined fishing nets abound (Wallace \& Gisborne 2006).

The literature on purported sea serpents is another source for documenting the early entanglement of marine life in pre-plastic fishing gear. For example, Bishop Pontopiddian, in his seminal The Natural History of Norway, the 1755 book which started the modern sea serpent phenomenon, provides one of the earliest descriptions of fisheries bycatch when describing sea monsters. In France (2016a), I provide three accounts of what were almost certainly whales misconstrued as sea monsters encountering fishing nets. One of the anecdotes, from 1912, goes as far as using the word "entanglement." De Camp and de Camp (1985) posited that one of the most famous sightings of all time, that made from the HMS Daedalus in 1848, could be explained by an animal pulling maritime debris. Additionally, there is Heuvelmans' (1968) interpretation behind the 1857 sighting of a sea serpent in South Africa (see France 2018). He stated that the "so-called body is so unlike any part of an animal that one cannot help thinking that it may have been a net or rope towed by a shark or porpoise which had got caught in it." This interesting interpretation was made at a time when the threat posed by entanglement was being ignored by marine biologists. Consequently, Heuvelmans, 
in his 1968 book that gave birth to the modern contemporary field of cryptozoology, described the typology of "many-humped" sea serpents as looking like "a string of buoys," although, with the exception of the 1857 UMO discussed above, he regarded these trashcyborgs as being real sea serpents. Loxton and Prothero (2013) touch upon this but do not elaborate further on the alternative and parsimonious explanation behind certain sightings of sea serpents.

It is important to recognize that eyewitnesses do not usually report having seen animals shaped like serpents. Instead, they describe a series of discrete coils, humps, or dark rounded objects ('like a string of buoys' is typical) and infer that they are connected beneath the water's surface. The problem, of course, is that such sightings are by their nature ambiguous; a humungous serpentine animal might resemble a string of buoys, but a group of smaller objects (say, an actual string of buoys) also might resemble a string of buoys.

However, by no means can all the encounters of the UMOs observed by thousands of eyewitnesses over the centuries be explained by entanglement. For example, anecdotal analysis suggested that only 20 of more than a hundred and fifty descriptions about purported sea serpents made in New England during the post-Tambora years between 1831 and 1925 (see O'Neill 1999) can be reinterpreted as being misidentified entangled animals (France 2019c). For Nova Scotian sea serpent sightings over a period of more than a century (Hebda 2015, France in prep.), less than a quarter seem to indicate that the observed animals were indeed entangled in fishing gear or other maritime debris.

In toto, then, for Nova Scotia, we have a limited group of animated UMOs which can be described as having highly flexible bodies of lengths equaling those of the largest whales but of only a narrow circumference. Against all laws of hydrodynamics, they are capable of rapid propulsion solely through vertical undulations in the absence of a tail or lateral fins. Furthermore, the bodies are described as being composed of a series of many segmented ridges or protuberances that are displayed as actually being above the surface of the water. The UMOs often seem oblivious to their surroundings and one is even unaffected by gunshot. Several exhibit what is thought to be a mane (perhaps netting) as well as scales (possibly glass floats). Most significantly, in three instances, UMOs were said to resemble "a 
Table 2 Observed physical and behavioral attributes of UMOs posited to have been entangled animals. Attributes are those used to describe the UMO observed in and around Gloucester in 1817, and clearly indicative of an animal entangled in marine debris (France 2019a). Numbers shown indicate the incidence of occurrence for 12 different Nova Scotian sightings between 1787 and 1939, 20 different sightings in New England between 1831 and 1925 (France 2019c), 28 different sightings of putatively entangled whales (France 2016b, 2018), and 16 different sightings of putatively entangled sea turtles (France 2016a, 2017).

\begin{tabular}{|c|c|c|c|c|}
\hline Attribute & Nova Scotia & New England & Cetaceans & Chelonians \\
\hline Notable length & 11 & 9 & 12 & 7 \\
\hline $\begin{array}{l}\text { Body composed of a series of } \\
\text { irregular, jointed component parts } \\
\text { (multiple humps, } \\
\text { coils, or a ridge) }\end{array}$ & 7 & 9 & 6 & 8 \\
\hline Rapid speed of movement & 5 & 3 & 6 & - \\
\hline Notable flexibility of body & 3 & 1 & 4 & 4 \\
\hline $\begin{array}{l}\text { Vertical undulating movement of } \\
\text { body segments }\end{array}$ & 5 & 3 & 3 & 4 \\
\hline $\begin{array}{l}\text { Body components likened to kegs } \\
\text { or barrels, and sometimes scales } \\
\text { or saucers }\end{array}$ & 8 & 2 & 3 & 4 \\
\hline $\begin{array}{l}\text { Oblivious of surroundings or } \\
\text { impervious to disturbance }\end{array}$ & 4 & 2 & 2 & 3 \\
\hline $\begin{array}{l}\text { Overall body likened to a string } \\
\text { of floats, kegs or buoys }\end{array}$ & 3 & 3 & 2 & 0 \\
\hline $\begin{array}{l}\text { Obvious trailing wake or water } \\
\text { disturbance }\end{array}$ & 6 & 2 & 2 & 3 \\
\hline $\begin{array}{l}\text { Floating motionless, gently swaying } \\
\text { in waves, or moving very slowly }\end{array}$ & g & 2 & 2 & 5 \\
\hline $\begin{array}{l}\text { Narrow, tapering, sinuous, snake/ } \\
\text { eel-like shape, often with absence } \\
\text { of a caudal fin or lateral appendages }\end{array}$ & s & 3 & 14 & 10 \\
\hline $\begin{array}{l}\text { Extended body pulled down into } \\
\text { water, thrown up into the air, } \\
\text { or thrashed about on the surface }\end{array}$ & 0 & 1 & 11 & 1 \\
\hline $\begin{array}{l}\text { Presence of a horn, spike, } \\
\text { spine, mane, or other protuberance } \\
\text { (sometimes identified as a head) }\end{array}$ & 3 & 2 & 5 & 6 \\
\hline
\end{tabular}

chain of hogsheads," a "long string of fishing-net buoys," or the "floats of a long net." Again, consider the aforementioned 'duck test' here. Paxton (2009) demonstrated that when anecdotes of anomalous phenomena, such as those pertaining to UMOs, are considered in aggregate, they can constitute data meritorious of legitimate scientific 
study. In this regard, Table 2 shows the concordance between the observed physical and behavioral characteristics of the Nova Scotian UMOs and those from the post-Tambora sightings in New England, as well as sightings from around the world which I believe to have been entangled whales and sea turtles. This is based on how closely their characteristics match those for the obviously entangled animal(s) observed in and around Gloucester (France 2019a).

One other sighting of notable mention explicitly links Nova Scotia 'sea serpents' to entanglement. In 1872, an UMO said to resemble a barrel floating upon the water of St. Margaret's Bay, was reported to have been "destroying the poor people's nets going through them, and rending them at its pleasure" (Hebda 2015, France, in prep.). Another sighting of a sixteen foot-long, two foot-circumference UMO was seen in 1865 "swimming and splashing" in the landwash (break zone of waves) while "apparently endeavouring to get ashore" near Peggy's Cove (Ambrose 1867). Given that there are no sea snakes anywhere in the Atlantic Ocean, the candidates for such a serpentine form are limited, with none displaying amphibious inclinations. In contrast, there are examples of the many-humped bodies of sea serpents, said to resemble strings of floats, that are sometimes seen to be temporarily draped upon the shore while the entangled animal at the other end is submerged (France 2017, 2019a,c). Elsewhere in Atlantic Canada, a two hundred foot-long "sea monster" was observed in 1888 off the west coast of Newfoundland that sported "a mane larger than that of any horse" (France, in prep.), which quite likely was entangled netting. And along the New Brunswick/Maine border in 1938, a fifty foot "snake-like creature" composed of a number of "plainly visible humps" separated by empty spaces "distanced between them" was seen in active pursuit of a school of porpoises (O'Neill 1999, France, in prep.). A sea serpent "in pursuit of" a school of porpoises is one explanation but another is that it is merely one of the porpoises pulling along a trailing string of floats of a herring net from which it had incompletely freed itself after becoming entangled.

\section{Entanglement: Conjectures and Implications}

Inferring non-lethal entanglement from accounts of sea serpent encounters is generally an easier task than is postulating the identity of the animal responsible for pulling the debris. That said, sometimes the accounts do make specific mention of animals. Often this takes the form of first assuming that the UMO is a known animal based on 
an initial resemblance. But then, upon further or closer observation, the extended body, or the tail of component parts that are noted are obviously incongruous with the supposed animal. This results in a second appraisal based on a popular belief in the existance of sea monsters which concludes that a sea serpent or sea monster is being seen (France 2019a). Entangled whales, sometimes thought to be engaged in battling elongated sea serpents (France 2016b), are often the most likely candidates (France 2018). Descriptions of strange creatures that look like Island of Doctor Moreau hybrids are frequently entangled sea turtles (France 2016c, 2017). In other cases, and for reasons mentioned earlier, basking sharks are also candidates (France 2019b).

For the Nova Scotian encounters focused on in the present paper, the "great bulk," shoal-like shape, and size "as large as a small dory" of Anecdotes 1 and 9 suggest a whale as the viewed animal. Indeed, the eyewitnesses of the latter account first supposed this along with those in Anecdote 3. In Anecdote 7 the three inch-long teeth or catfish like barbels seen inside the red mouth of the UMO sighted are exactly what a leatherback turtle looks like when it displays the horny papillae on its palate (Brongersma 1968, France 2017). The "horny textured...shell-like" head of the UMO in Anecdote 8 also reads like the body of a leatherback turtle, as does the notable presence of "rows of glistening teeth" to that animal's papillae. However, the buccal description also fits for the rows gill-rakers inside the long, pointy-snout of a basking shark (Heuvelmans 1968), animals that were often misidentified as sea serpents (Speedie 2017, France 2019b).

It is likely that there has been a bycatch of non-targeted species ever since fishing began (Alverson et al. 1994; Saila 1983), and that this may have played a role in the decline of certain species in medieval Europe (Bolster 2012). This, in turn, led to the attraction, exploitation, and eventual colonization of the North American seaboard (Pope 2004), given that herring were the staff of life in Christian Europe.

Life for non-lethally entangled animals, then as now, would not have been ideal with impaired swimming ability from pulling around a net and floats (Feldkamp et al. 1989). Such animals, especially today when they have struggled free from synthetic lines, experience health problems. Many entangled animals display wounds from the abrasion and cutting action of the debris (Derraik 2002). This in- 
creases their long-term risk of infection. Fully eighty percent of all humpback whales surveyed in New England today carry scars from entanglement with fishing gear (Johnson 2005), which makes this an issue of deep concern.

The significance of the present environmental history is its suggestion, based on examination of anecdotal evidence compiled from eyewitness encounters with purported sea serpents, that marine animals in Nova Scotia have been subjected to pressure not only from direct fishery exploitation (Mowat 1997) but also from being bycatch due to entanglement in deployed gear, for a much longer period than commonly presumed. Entanglement is recognized to be a serious problem in the region today (e.g. Goodman et al. 2019, Myers et al. 2019, France 2019a) and has probably been a factor for several hundred years (France 2019c).

Finally, to some it may seem remarkable that so many eyewitnesses failed to recognize and identify in writing a train of fishing equipment, hunting gear, or other maritime debris in the process of being dragged behind an entangled animal. However, go online today and it is possible to find photographs of unfortunate animals pulling long lines of entangled debris, that from a distance, do assume a serpentine form. This is especially the case when the debris of floats, netting, and entwined ropes are festooned with seaweed, the whole taking on an appearance of solidity. Back in the nineteenth century, even experienced mariners and fishermen were fooled. Often, it was not until they were within a few metres of the UMO that the deception became recognized, as for example: "a closer and more critical inspection had taken place, and the supposed sea-monster turned himself into a long dark root, gnarled and twisted, of a tree, secured to the moorings of a fishing net, with the strong tie passing it rapidly, and thus giving it an apparent life-like movement and serpentine aspect" (France 2018). And that was for an UMO that was fastened at one end to a pier. If there is also movement, due to the netting and floats bobbing up and down as a result of being attached to a live animal swimming about in the open ocean, it becomes easy to imagine that the observed creature was a famous sea serpent that was creature fleetingly glimpsed. Furthermore, there was the often considerable observation distance and short duration of sightings that added to uncertainty. In one remarkable case, it was not until the supposed sea serpent was actually hoisted onto the deck of the 
ship for close examination, following it being shot at, captured, and dragged behind a dory, that its true inanimate nature was revealed (Oudemans 1892). An examination of the background of observers of the Gloucester UMO, the most sighted and studied 'sea serpent' in history, revealed that similar conclusions were reached irrespective of whether eyewitnesses were wet-behind-the-ears landlubbers or old experienced salty-dogs (France 2019a). With the widespread belief in the existence of antediluvian creatures, sea serpents abound. If one wants to observe a sea serpent, this is always easy, for both nature and human action provide many opportunities to provide believable doppelgangers. Surveys of nineteenth-and twentieth-century sightings of UMOs revealed that conclusions made that sea monsters were being seen occurred irrespective of viewing distance and prior experience of eyewitnesses (Paxton 2009, Paxton \& Shine 2016). Confirmation bias (i.e. believing is seeing) has always exerted a strong influence on receptive minds with respect to sea serpents. In the past, this was due to the widely accepted theories of natural history (Brown 1990, Westrum 1979, Lyons 2009, France 2019a). In more recent times, this has occurred as a consequence of the popularity of cryptozoology speculations (Dendle 2006, Loxton \& Prothero 2015, Rossi 2016, France 2019a). Given the strength of these belief systems, it should be of no surprise that it is literally possible to conjure up an aquatic cryptid right out of the air (Lehn 1981, Lehn and Schroeder 1981).

Acknowledgements The library staff at Dalhousie University and archival staff at the Mystic Seaport Museum are thanked for their assistance. This work is dedicated to the memory of Reverend John Ambrose, an enthusiastic natural historian and antiquarian of Nova Scotia, and a frequent contributor to these pages in the nineteenth century.

\section{REFERENCES}

Aiken, W.R.G. \& Purser, J. (1936). The preservation of fibre ropes for use in sea-water. Plymouth Laboratory New Series 20: 643-654.

Al-Abdulrazzak D., Naidoo R., Palomares, M.L.D. \& Pauly D. (2012). Gaining perspective on what we've lost: The reliability of encoded anecdotes in historical ecology. PLOS One 7: 1-5. 
Alexander, K.E. \& Others. (2017). Tambora and the mackerel year: Phenology and fisheries during an extreme climate event. Science Advances $3: 1-18$.

Alverson, D.L., Freeberg, M.H., Murawski S.A. \& Pope J.G. (1994). Aglobal assessment of fisheries bycatch and discards. Fisheries and Oceans Fisheries Technical Paper 339.

Ambrose, Rev. J. (1867). Some account of the petrel-the Sea Serpent-and the albacore - as observed at St Margaret's Bay, - together with a few observations on a beach mound or kitchen midden, near French Village. Proceedings and Transactions of the Nova Scotian Institute of Science 1: 34-44.

Anonymous. (2019a). Dead whale was tangled in rope in East Lothian for 'months'. BBC News 25/04/19. www.bbc.com/news/uk-scotlandedinburgh-east-fife-48051954.

Anonymous. (2019b). Whale washed up in Caithness tangled in Canadian fishing gear. BBC News, 03/06/19. www.bbc.com/news/uk-scotlandhighlands-islands-48497046.

Bauer, H.H. (2013). Cryptozoology and the troubles with 'skeptics' and mainstream pundits. Journal of Scientific Exploration 27: 690-704.

Bekker-Nielsen, T. \& Casola, D.B. (eds.) (2010). Ancient nets and fishing gear. Aarhus University Press, Aarhus, Denmark.

Bolster, W.J. (2012). The mortal sea: Fishing the Atlantic in the age of sail. Harvard University Press, Cambridge, MA.

Brongersma, L.D. (1968). The Soay beast. Beaufortia 15: 33-46.

Brown, C.M. (1990). A natural history of the Gloucester sea serpent: Knowledge, power, and the culture of science in Antebellum America. American Quarterly 42: 402-436.

Burns, E.I. (2014). Monster on the margin: The sea serpent phenomenon in New England, 1817-1849. Ph.D. Thesis, Department of History, University of Buffalo, Buffalo, NY.

Camuffo, D. (2001). Canaletto's paintings open a window on the relative sea level rise in Venice. Journal of Cultural Heritage 4: 227-281.

Crumley, C.J. (ed.). (1994). Historical ecology: Cultural knowledge and changing landscapes. School for Advanced Research Press, Santa Fe, New Mexico.

Culbertson-Paoli, M., Farro, L., Long, A. \& Wilkinson, S. (2019). In search of a climate change signal in Nova Scotia: The Alexander Mackay data, 1901-1923. Proceedings of the Nova Scotian Institute of Science 50(1): 131-163.

Da Silva T.C., Medeiros P.M., Balcázar A.L., de Sousa Araújo T.A, Pirondo A., \& Trindade Medeiros, M.F. (2014). Historical ethnobiology: An overview of selected studies. Ethnobiology and Conservation DOI: http://dx.doi.org/10.15451/ec2014-6-3.4-1-12.

Dearborn, D. (1998). New Brunswick sea stories. Miscellaneous Consignment. 
Dearing, J.A., Acma, B., Bub, S., Chambers, F.M., Chen, X., Cooper, J. et al. (2015). Social-ecological systems in the Anthropocene: The need for integrating social and biophysical records at regional scales. The Anthropocene Review2(3): 220-246. https://doi.org/10.1177/2053019615579128.

de Camp, L.S. \& de Camp, C.C. (1985). The day of the dinosaur. Bonanza Books.

Dendle, P. (2006). Cryptozoology in the medieval and modern worlds. Folklore 117: 190-206.

Derraik, J.G.B. (2002). The pollution of the marine environment by plastic debris: A review. Marine Pollution Bulletin 42: 842-852.

Drew, J., Philipp, C.\& Westneat, M.W. (2013). Shark tooth weapons from the $19^{\text {th }}$ century reflect shifting baselines in central Pacific predator assemblies. PLOS ONE 8(4): e59855. https://doi.org/10.1371/journal.pone.0059855

Fairfax, D. (1998). The Basking Shark in Scotland - Natural History, Fishery and Conservation. Tuckwell Press, East Linton, England.

Fama, E. (2012). Debunking a great New England sea serpent. www.tor. com, 16/08/12.

Feldkamp, S.D., Costa, D.P. \& DeKrey, G.K. (1989). Energetic and behavioral effects of net entanglement on juvenile northern fur seals (Callorhinus ursinus). Fishery Bulletin 87: 85-94.

France, R.L. (2010). Expanding ecosystem goods and services: Climate change, phenology, and the building of citizen 'scientists.' p. 143-152 In Liotta, P.H. \& Others (eds.). Achieving Environmental Security: Ecosystem Services and Human Welfare. IOS Press.

France, R.L. (2016a). From land to sea: Governance-management insights from terrestrial restoration research useful for developing and expanding social-ecological marine restoration. Ocean \& Coastal Management 133: 64-71.

France, R.L. (2016b). Reinterpreting nineteenth-century accounts of whales battling 'sea serpents' as an illation of early entanglement in preplastic fishing gear or maritime debris. International Journal of Maritime History 28: 686-714.

France, R.L. (2016c). Historicity of sea turtles misidentified as sea monsters: A case for the early entanglement of marine chelonians in pre-plastic fishing nets and maritime debris. Coriolis: Interdisciplinary Journal of Maritime Studies 6: 1-24.

France, R.L. (2017). Imaginary sea monsters and real environmental threats: Reconsidering the famous Osborne, 'Moha-moha', Valhalla, and 'Soay beast' sightings of unidentified marine objects. International Review of Environmental History 3: 63-100.

France, R.L. (2018). Illustration of an 1857 'sea serpent' sighting reinterpreted as an early depiction of cetacean entanglement in maritime debris. Archives of Natural History 45: 111-117. 
France, R.L. (2019a). Disentangled: Ethnozoology and environmental explanation of the Gloucester Sea Serpent. Wageningen Academic Press, Wageningen, The Netherlands.

France, R.L. (2019b). Ethnobiology and shifting baselines: An example reinterpreting the British Isles' most detailed account of a sea serpent sighting as early evidence for pre-plastic entanglement of basking sharks. Ethnobiology and Conservation 8: 1-31.

France, R.L. (2019c). Extreme climatic upheaval, emergency resource adaptation, and the emergence of folkloric belief: Geomythic origin of sea serpents from animals becoming entangled in fishing gear during New England's nineteenth-century social-ecological crisis. Human Ecology 47: 499-513.

Gardner, D. (2007). Whale survives harpoon attack 130 years ago to become 'world's oldest mammal'. The Daily Mail, London, UK. 13/06/2007.

Goode, G.B. \& Others. (1884). The fisheries and fishery industries of the United States. United States Bureau of Fisheries. Washington Govt. Print. Off., 1884-87. National Oceanographic and Atmospheric Administration reprinting. http://doi.org/10.5962/bhl.title.33056.

Goodman, A.J., Brillant, S., Walker, T.R., Bailey, M. \& Callaghan, C. (2019). A ghostly issue: Managing abandoned, lost and discarded lobster fishing gear in the Bay of Fundy in Eastern Canada. Ocean \& Coastal Management 181: 104925.

Gregory, M. R. (2009). Environmental implications of plastic debris in marine settings - Entanglement, ingestion, smothering, hangers-on, hitch-hiking and alien invasions. Philosophical Transactions of the Royal Society B 364: 2013-2025.

Harrington, C.R. (Ed.). (1992). The year without a summer? World climate in 1816. Canadian Museum of Nature, Ottawa, ON.

Hebda, A.J. (2015). The serpent chronicles: Sea serpents and other marine creatures from Nova Scotia's history - A book about stories. Natural History Museum of Nova Scotia, Halifax, NS.

Heuvelmans, B. (1968). In the wake of the sea-serpents. Hill and Wang, Farrar, Straus and Giroux, New York, NY.

Johnson, T. (2005). Entanglements: The intertwined fates of whales and fishermen. University Press of Florida, University of Florida, Gainesville, FL .

Kristjonsson, H. (1971). Modern fishing gear of the world 3: Fishing gear, purse seining, aimed trawling. Food and Agriculture Organization, United Nations, Rome, Italy.

Laist, D.W. (1997). Impacts of marine debris: Entanglement of marine life in marine debris including a comprehensive list of species with entanglement and ingestion records. In J. M. Coe, J.M. \& Rogers, D.B. (eds.), Marine debris: Sources, impacts and solutions. Springer Publ. Co., New York, NY.

Lehn, W.H. (1979). Atmospheric refraction and lake monsters. Science 205: 183-185.

Lehn, W.H. \& Schroeder, I. (1981). The Norse merman as an optical phenomenon. Nature 293: 362-366. 
Lord, J.H. (1866). The two views of the sea-serpent. Beadle's Monthly, Magazine of Today 11: 402-412.

Lotze, H.K. \& Worm, B. (2009). Historical baselines for large marine animals. Trends in Ecology and Evolution 24: 254-262.

Lotze, H.K., Lenihan, H.S., Bourque, B.J., Bradbury, R.H., et al. (2006). Depletion, degradation, and recovery potential of estuaries and coastal seas. Science 312: 1806-1809.

Loxton, D. \& Prothero, D.R. (2015). Abominable science! Yeti, Nessie, and other famous cryptids. Columbia University Press, Columbia University, New York, NY.

Lyell, Sir C. (1850). A second visit to the United States of North America. Harper and Brothers, New York, NY.

Lyons, S.L. (2009). Species, serpents, spirits, and skulls: Science at the margins in the Victorian Age. State University of New York Press, Albany, NY.

Magin, U. (1996). St George without a dragon. Bernard Heuvelmans and the sea serpent. Fortean Studies 4: 223-234.

McCaskill, J. (2009). Conserving waterlogged rope: A review of traditional methods and experimental research with polyethylene glycol. MA Thesis, Texas A\&M University, College Station, TX.

McClenachan, L. (2009). Documenting loss of large trophy fish from the Florida Keys with historical photographs. Conservation Biology 23: 636643.

McClenachan, L., Ferretti, F. \& Baum, J.K. (2012). From archives to conservation: Why historical data are needed to set baselines for marine animals and ecosystems. Conservations Letters 5: 349-359.

Meine, C. (1999). It's about time: Conservation biology and history. Conservation Biology 13: 1-3.

Miller, A.J. \& Primack, R.B. (2008). Global warming and flowering times in Thoreau's Concord: A community perspective. Ecology 89: 332-340.

Mowat, F. (1997). Sea of Slaughter. McClelland-Bantam, Toronto, ON.

Myers, H.J., Moore, M., Baumgartner, M.F., Brillant, S.W., et al. (2019). Ropeless fishing to prevent large whale entanglements: Ropeless consortium report. Marine Policy 107: 103587. https://doi.org/10.1016/j.marpol. 2019.03587.

Narchi, N.E., Cornier, S., Canu, D.M., Aguilar-Rosas, L.E., Bender, M.G., Jacquelin, C., Thiba, M., Moura, G.G.M. \& de Wit, R. (2013). Marine ethnobiology a rather neglected area, which can provide an important contribution to ocean and coastal management. Ocean \& Coastal Management 89: 117-126.

National Oceanic and Atmospheric Administration. (NOAA). (2014). Report on the entanglement of marine species in marine debris with an emphasis on species in the United States. Silver Spring, MD: National Oceanic and Atmospheric Administration Marine Debris Program.

O'Neill, J.P. (1999). The great New England sea serpent: An account of unknown creatures sighted by many respectable persons between 1638 and the present day. Down East Books, Camden, ME. 
Oudemans, A.C. (1892). The great sea-serpent. Coachwhip Publications (2007 facsimile reprinting), Greenville, $\mathrm{OH}$.

Parsons, E.C.M. (2004). Sea monsters and mermaids in Scottish folklore: Can these tales give us information on the historic occurrence of marine animals in Scotland? Anthrozoös 17: 73-80.

Pauly, D. (1995). Anecdotes and the shifting baseline syndrome of fisheries. Trends in Ecology and Evolution 10: 430.

Paxton, C.G.M. (2009). The plural of 'anecdote' can be 'data': Statistical analysis of viewing distances in reports of unidentified large marine animals 1758-2000. Journal of Zoology 279: 381-387.

Paxton, C.G.M. \& Naish, D. (2019). Did nineteenth century marine vertebrate fossil discoveries influence sea serpent reports? Earth Sciences History 38: 16-27.

Paxton, C.G.M. \& Shine, A.J. (2016). Consistency in eyewitness reports of aquatic 'monsters'. Journal of Scientific Exploration 30: 16-26.

Peters, R.H. (1980). From natural history to ecology. Perspectives in Biology and Medicine 23: 191-203.

Peters, R.H. (1991). A critique for ecology. Cambridge University Press, Cambridge, UK.

Pope, P.E. (2004). Fish into wine: The Newfoundland plantation in the seventeenth century. University of North Carolina Press, Chapel Hill, NC.

Rice, P.M., Rice, D.S. \& Pugh, T.W. (2017). Small things forgotten: Artifacts of fishing in the Petén Lakes region, Guatemala. Contributions in Ethnobiology. Society of Ethnobiology, University of Puget Sound, Tacoma, WA. 102 p.

Rossi, L. (2016). A review of cryptozoology: Towards a scientific approach to the study of 'hidden animals.' In: Angelici, F.M. (ed.) Problematic Wildlife. Springer Publ. Co., New York, NY.

Salia, S. (1983). Importance and assessment of discards in commercial fisheries. FAO Circular 765, Food and Agriculture Organization, United Nations, Rome, Italy.

Saenz-Arroyo, A., Roberts, C.M., Torre, J. \& Carino-Olvera, M. (2005). Using fishers' anecdotes, naturalists' observations and grey literature to reassess marine species at risk: The case of the Gulf grouper in the Gulf of California, Mexico. Fish and Fisheries 6: 121-133.

Saenz-Arroyo, A., Roberts, C.M., Torre, J., Carino-Olvera M. \& Hawkins, J.P. (2006). The value of evidence about past abundance: Marine fauna of the Gulf of California through the eyes of $16^{\text {th }}$ to $19^{\text {th }}$ century travellers. Fish and Fisheries 7: 128-146.

Soini, W. (2010). Gloucester's sea serpent. The History Press, Cheltenham, Gloucestershire, UK.

Speedie, C. (2017). A sea monster's tale: In search of the basking shark. Wild Nature Press, John Wiley and Sons, Hoboken, NJ.

Starkey, D.J., Holm, P. \& Barnard, M. (eds.). (2007). Oceans past: Management insights form the history of marine animal populations. Routledge, Taylor and Francis Group, New York, NY. 
Szabo, V. (2018). Northern seas, marine monsters, and perceptions of the premodern North Atlantic in the longue durée. In Visions of North in Premodern Europe, Jorgensen, D. and Langum, V. (eds.). pp. 145-182. Brepols Publishers NV, Turnhout, Belgium.

Van Duzer, C. (2013). Sea monsters on medieval and renaissance maps. The British Library, London, UK.

Vasseur, L., Guscott, R.L. \& Mudue, P.J. (2001). Monitoring of spring flower phenology in Nova Scotia: Comparisons over the last century. Northeastern Naturalist 8: 393-402.

Vegter, A.C., Barletta, M., Beck, C., Borrero, J, et al. (2014). Global research priorities to mitigate plastic pollution impacts on marine wildlife. Endangered Species Research 25: 225-247. DOI: https://doi.org/10.3354/ esr00623.

Wabnitz, C. \& Nicols, W.J. (2010). Plastic pollution: An ocean emergency. Marine Turtle Newsletter 129: 1-4.

Wallace, S. \& Gisborne, B. (2006). Basking sharks: The slaughter of B.C.'s gentle giants. Transmonanus.

Westrum, R. (1979). Knowledge about sea serpents. In Wallis, R. (ed.). On the Margins of Science: The Social Construction of Rejected Knowledge. University of Keele, Newcastle, UK.

Wilcocks, J.C. (1884). The sea-fisherman, comprising the chief methods of hook and line fishing in the seas, and remarks on nets, boats, and boating. Forgotten Books reprinting.

Wood, G.D. (2014). Tambora: The eruption that changed the world. Princeton University Press, Princeton, NJ. 
